Отримано: 19 грудня 2019 р.

Прорецензовано: 8 січня 2020 р.

Прийнято до друку: 13 січня 2020 р.

e-mail: maleev@ippo.dn.ua

DOI: $10.25264 / 2415-7384-2020-10-37-45$

Denys Malieiev,

PhD (Candidate of Psychological Sciences), Associate Professor of the Department of Personal Psychology and Development, Donetsk Regional Institute of Postgraduate Pedagogical Education

Ihor Lantukh,

PhD in Economic, associate professor, associate professor of the department of Department of Psychiatry, Narcology, Neurology and Medical Psychology V. N. Karazin Kharkiv national University

\title{
PSYCHOLOGICAL STRUCTURE OF PERSONAL RELIABILITY OF SUBJECTS OF ENTREPRENEURIAL ACTIVITY
}

The article is devoted to research of psychological structure of personal reliability of subjects of entrepreneurial activity. The purpose of the article is to highlight and substantiate the results of empirical research of the psychological structure of personal reliability in business entities. Personality reliability of subjects of entrepreneurial activity includes moral and legal and pro-social, humanistic-oriented values that correspond to the ethics of the chosen professional activities and provide for the recognition of social significance and personal responsibility for the results of entrepreneurial activity. The structure of individual psychological peculiarities of subjects of entrepreneurial activity with different levels of personal reliability is determined. The results of correlation, factor analysis of individual psychological peculiarities of entrepreneurs, which determine the level of personal reliability of subjects of entrepreneurial activity, are presented. A typology of personal reliability (axiological, proactive, prosocial, praxeological, synergetic, and innovative) is also proposed.

Keywords: personal reliability, subjects of entrepreneurial activity, individual psychological characteristics.

Малєєв Денис Вікторович,

кандидат психологічних наук, доцент кафедри психологї̈ та розвитку особистості

Донецького обласного інституту післядипломної педагогічної освіти

Лантух Ігор Валерійович,

гандидат економічних наук, дочент, дочент кафедри клінічної неврології, психіатрії та наркологї

Харківського національного університету ім. В. Н. Каразіна

\section{ПСИХОЛОГІЧНА СТРУКТУРА ОСОБИСТІСНОЇ НАДІЙНОСТІ СУБ'ЄКТІВ ПІДПРИЕМНИЦЬКОї ДІЯЛЬНОСТІ}

Статтю присвячено дослідженню психологічної структури особистісної надійності суб'єктів підприємнищької діяльності. Визначено структуру індивідуально-психологічних особливостей суб'єктів підприємницької діяльності з різним рівнем особистісної надійності. Особистісна надійність суб'єктів підприємницької діяльності містить морально-правові та просочіальні, гуманістично-орієнтовані иінності, які відповідають етиці обраної професійної діяльності та передбачають усвідомлення соціальної значущчості й особистісної відповідальності за результати підприсмницької діяльності. Крім ицього, структуру надійності визначають концепти активності, відповідальності, самодостатності, інтегральності та цільності Я-концепиії особистості; соиіальні якості, які характеризують за своїм змістом просочіальність особистості.

Особистісна надійність - це не пасивна інтеграчія впливу зовнішніх і внутрішніх умов існування, а результат акумуляиії способів досягнення мети, адаптивних можливостей і розширення репертуару стратегій поведінки подолання критичних ситуацій, сформованих у суб 'єктів підприємницької діяльності в процесі професійної і особистісної самореалізачії. Наведено результати корелящійного, факторного аналізу індивідуально-психологічних особливостей підприємиів, які обумовлюють рівень їхньої особистісної надійності. Запропоновано типологію особистісної надійності (аксіологічний, проактивний, просочіальний, праксеологічний, синергетичний, інноваційнісний).

Ключові слова: особистісна надійність, суб'єкти підприємницької діяльності, індивідуально-психологічні характеристики особистості підприємия.

Formulation of the problem. Economic stability and welfare of the population, innovation and the use of advanced technologies, the practical absence of corruption and the high level of public confidence in the state structures are above all the results of a developed socially responsible business, which not only earns money, but also worries about socially vulnerable sectors of society. As the main attribute of a market economy, entrepreneurship becomes an inalienable feature of the psychological readiness of citizens for their respective activities. Citizen's focus on entrepreneurship requires special psychological support and often correction of decisions on personal determinants of professional training [9].

Наукові записки Національного університету «Острозька академія», серія «Психологія», № 10, січень, 2020 р. 
Personality reliability of business entities is a special phenomenon in which at the subjective level the integrative quality of professional readiness of the professional manifests the achievement of stability of positive results of professional activity in the field of «man - man». By its nature, the personal reliability of the specialists of the socionomic sphere is the acquired quality, which is determined by the combination of certain personal characteristics and the characteristics of entering into professional activity [18].

Analysis of recent research and publications. Within the psychological problems of the functioning and development of modern business foreign and Ukrainian scientists are solving, first of all, the following issues: psychological factors of professional burnout in entrepreneurs (G.V. Gnuskina) [2], formation of the motivational sphere of entrepreneurial activity (L.M. Karamushka, N.Yu. Khudyakova) [3]; psychology of professional morality of entrepreneurs (M.O. Kononets) [4]; studying the peculiarities of entrepreneurial activity development of the personnel of educational organizations (O.V. Kredentser) [6]; psychological factors in the development of entrepreneurial skills (T.Yu. Kulakovsky) [7]; personal determinants of successful training of future entrepreneurs (N.M. Kulbida) [8]; psychology of the development of environmentally oriented business activities (O. M. Palamarchuk) [14]; the concept of moral and legal reliability of personality (E. Yu. Strizov) [16].

However, the majority of the entrepreneurial personality models described in the studies are based on individual properties of the individual. The identity of the entrepreneur as an integrity, with the formation of the moral and ethical aspects of its activities is almost not investigated. There is no single methodological approach to the problem, no attention has been paid to the personality traits and characteristics that provide the personal reliability of business entities, the features and ways of development of personal components as leading in the development of the ability of specialists to self-determination in the field of entrepreneurship and the implementation of functions of economic self-control [9].

The purpose of the article: to highlight and substantiate the results of empirical research of the psychological structure of personal reliability of business entities.

Objectives of the study: to provide data of correlation, factor analysis of individual and psychological characteristics of entrepreneurs, which determine the level of personal reliability of subjects of entrepreneurship and on the basis of the results to offer a typology of personal reliability of entrepreneurs.

Research methods. In the process of theoretical study of the problem and scientific and experimental work, both general scientific and special research methods were used:

a) theoretical: analysis of scientific literature and guidance documents related to the organization of entrepreneurial activity in Ukraine, generalization of received information, system analysis and interpretation of empirical data, classification, construction of analogies, structural and functional modeling;

b) empirical: «Personality questionnaire on the moral and legal reliability of the individual» (E. Yu. Strizov); Expert assessment of the employee's personality (B.G. Bovin); «GET TEST» General Test for Entrepreneurship (GET TEST); «Multilevel personal questionnaire» Adaptability» (O.G. Maklakov, S.V. Chermyanin); «Diagnosis of the polytheistic tendencies in the «II»-concept of personality» (S.M. Petrov); method of diagnostics of professional orientation of the person (B. Bass); «SACS» («Strategies for Overcoming Stress Situations») C. Hobfoll; «Coping Test» (R. Lazarus); Kirton Adaptation-Innovation Inventory (KAI) test; J. Bruner's «Profile of Thinking»; Methodology for Diagnostics of Social Intelligence by J. Guilford and M. Sullivan (adaptation of O.S. Mikhailova); «Test of sensual life orientations» D.O. Leontiev (modification of the methodology «Purpose-in-Life» by J. Krambo, L.Maholik); «Anchor Careers» Methodology for Diagnosis of Values Orientation in Career (E. Shein, translation and adaptation V.A. Chiker, V.E. Vinokurova); «Diagnosis of self-actualization of personality» (A.V. Lazukin, in the adaptation of N.F. Kalina) is an adapted version of the Personal Orientation Inventory by E. Shostrom; «Investigation of volitional self-control» (A.V. Zverkov, E.V. Eidman); questionnaire «EMIN» (D.V.Luxin); Methodology for the diagnosis of emotional maturity of the personality «MDEZO» (O.S. Kocharyan, M.A. Piven).

c) methods of mathematical statistics (correlation analysis, factor analysis), which provide a qualitative and quantitative analysis of the results. Empirical data obtained in the course of this study, were statistically processed using standard and tested programs for personal computers. Specialized application packages for psychological research («SPSS» and «Microsoft Office Excel») were used to provide commonly used onedimensional statistics and multidimensional mathematical and statistical methods.

Presentation of the main research material. The research was conducted in 2015-2018. The survey was attended by entrepreneurs of Donetsk $(n=238)$ and Poltava $(n=210)$ regions. In total, 448 entrepreneurs were surveyed. The empirical study involved several stages. At the first stage of the study, the methodological foundations of the problem of identifying the psychological factors of ensuring the reliability of business entities were studied, the theoretical model of the study was developed, the methods were selected, the collection of empirical material and its accumulation were carried out. In order to identify the structure of individual psychological characteristics of entrepreneurs with different levels of personal reliability, a correlation analysis was performed using $r$ - Pearson criterion. The results of the correlation analysis were presented as a correlation galaxy for each group of subjects, consisting of vertices that correspond to the characteristics of the studied variables connected by the lines, showing statistically significant relationships between the variables (Fig. 1-3). 
The results of this research allowed to reveal the structure of individual and psychological characteristics of entrepreneurs with the optimal level of reliability. So among the common characteristic tendencies in the value and semantic sphere of entrepreneurs in this category is important to observe the observance of traditional moral values, the desire to live in truth and conscience. They take into account and apply traditional moral standards in their behavior. Recognize their personal responsibility to other people for the observance of moral norms. Understand the need to adhere to these norms. Persistent to the norms of selfish, pragmatic and criminal morals. In assessing the results of their activities, the category of «labor» and «money» are used in close connection with the category of equity. Overnight activity is a completely normal attitude to work. It is inclined to exhibit such moral qualities as conscientiousness, justice, selflessness, generosity, openness, sincerity, truthfulness, modesty.

That is, the psychological mechanism that determines the functioning of the system of reliability, is the moralsemantic determination of the behavior of the individual. Thus, we assume that the moral-semantic processes have a significant impact on the cognitive, emotional, motivational and behavioral spheres of the psyche [11].

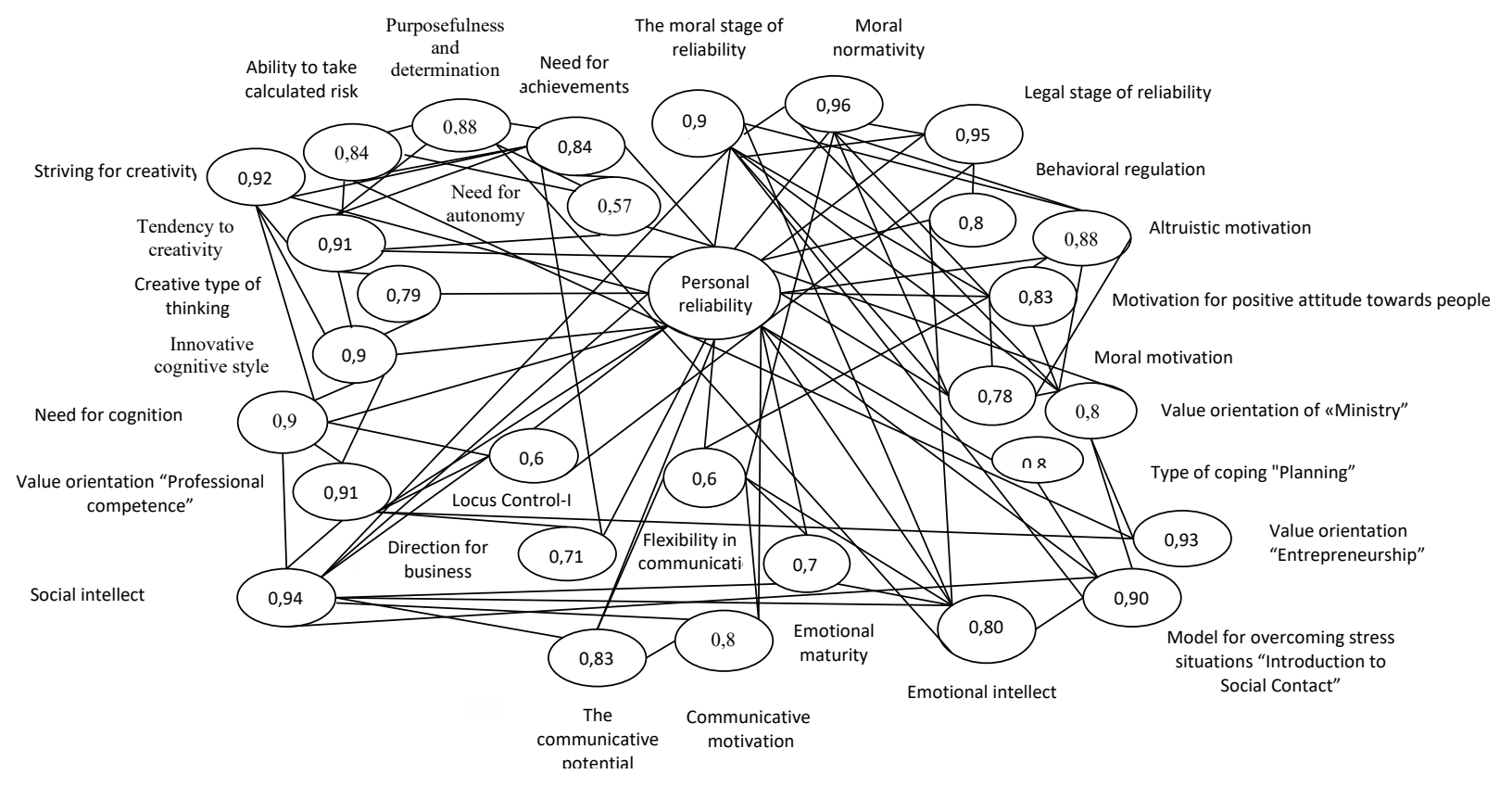

Fig. 1. Correlation of the individual psychological characteristics
of the subjects with an optimal level of personal reliability

Also, entrepreneurs with the optimal level of reliability are different self-identification and independence from the social environment, the ability to withstand social pressure. That corresponds to the perception of yourself as a strong person with sufficient freedom of choice to build his life in accordance with his goals and ideas about his meaning. Are in the constant process of developing their capabilities and potentials.

For this category, the characteristic characteristic of value orientations is the «entrepreneurship» as a crosscutting competence that is realized in the content and results of the activity: taking on the initiative; planning and management; work with ambiguity, uncertainty and risks; cooperation with other persons; learning through experience in the process of activity; self-efficacy; resource mobilization; financial and economic literacy mobilization of other persons; identification of opportunities; prognostication.

Another of the key value orientations for entrepreneurs with the optimal level of reliability is the value «Serving» - the desire to be useful and devotion to the cause, the realization of a socially important goal, motivated in its activities to all prosocial motives: altruism; positive attitude towards people; adherence to morality. The focus on the case, or the orientation on the task, reflects the advantage of the motives, the emergence of which is due to the capture of the process of work, the altruistic attitude to knowledge, the acquisition of new professional skills and abilities. Entrepreneurship involves the activities of an entrepreneur who is the creator of his own business, he can create both a new profession and an industry in the existing professions, he is a social innovator. As evidenced by innovative cognitive styles, propensities and aspirations for creativity and creative thinking, they favor the unstructured and often changing conditions of work. Their approach consists in re-evaluating and redefining the problems and conditions in which they arose, and, accordingly, in obtaining unexpected decisions, generating the idea of radical change. They have increased sensitivity to problems, to the deficit or contradictory knowledge, the actions to determine these problems, to find their solutions based on hypotheses, to test and change hypotheses, to formulate the result of the solution. 
Another feature of entrepreneurs with the optimal level of reliability is their ability to recognize the structure of interpersonal situations in the dynamics. They are able to analyze complex situations of interaction of people, understand the logic of their development, sensory to change the meaning of the situation when the inclusion of various participants in the communication. Also inherent ability to adequately reflect the goals, intentions, needs of participants of communication and the consequences of their behavior. In addition, it requires the ability to navigate in non-verbal situations of a person, as well as rules and regulations that govern the behavior in society.

As a rule, they are successful communicators. They are characterized by contact, openness, tact, benevolence and cordiality, a tendency toward psychological closeness in communication. Ability to extract maximum information about the behavior of people, to understand the language of non-verbal communication, to give quick and accurate judgments about people, to successfully predict their reactions in appropriate circumstances, to show a vision in relations with others, contributing to their successful social adaptation. They have a strong interest in self-knowledge and a developed ability to reflect. They are easy to use in a team, contribute to maintaining an optimal psychological climate, show more interest, cleverness and ingenuity in the work.

Using the «pro-social» strategy to overcome stress is reflected in joint efforts with others to more effectively resolve the critical situation, is a characteristic desire to share their experiences with other people, discuss the situation with them, find their sympathy and understanding. The presence in the behavioral models of processional coping strategies determines the effectiveness of the activity in the «man-man» system, since many life stressors are interpersonal, and even individual efforts to overcome have potential social consequences, the action of overcoming often requires interaction with other people. The leading type of coping behavior for this group is - «planning», which is manifestation in overcoming problems due to purposeful analysis of the situation and possible behavioral variants, development of a strategy for solving the problem, planning their own actions, taking into account objective conditions, past experience and available resources, as well as overcoming negative experiences in connection with the problem due to purposeful suppression and restraint of emotions, minimizing their influence on the perception of the situation and the choice of behavior strategy, high control of the Daniks, a desire for self-control.

The peculiarity of the emotional sphere of entrepreneurs with an optimal level of reliability is characterized by the presence of a whole spectrum of competencies revealed in the cognitive (understanding both their emotions and other people, perception, evaluation and expression of emotions, the use of emotions to increase the efficiency of thinking and activity), reflexive (awareness of emotions), regulatory (management of emotional states, self-regulation of emotional states) and personality aspects (tendency to empathy, internality, adaptability, etc.). They can understand the feelings of others, respect their emotions, sympathize and empathize. Therefore, they can put themselves in the position of other people and not perceive the appearance of emotions as a personal image. Able to learn from their mistakes, are able to maintain a balance between personal and professional life, without falling into any extreme.

The correlation analysis carried out between the individual and psychological characteristics of entrepreneurs with a sufficient level of personal reliability, made it possible to establish that reliability has a close positive relationship with the following indicators (Fig. 2).

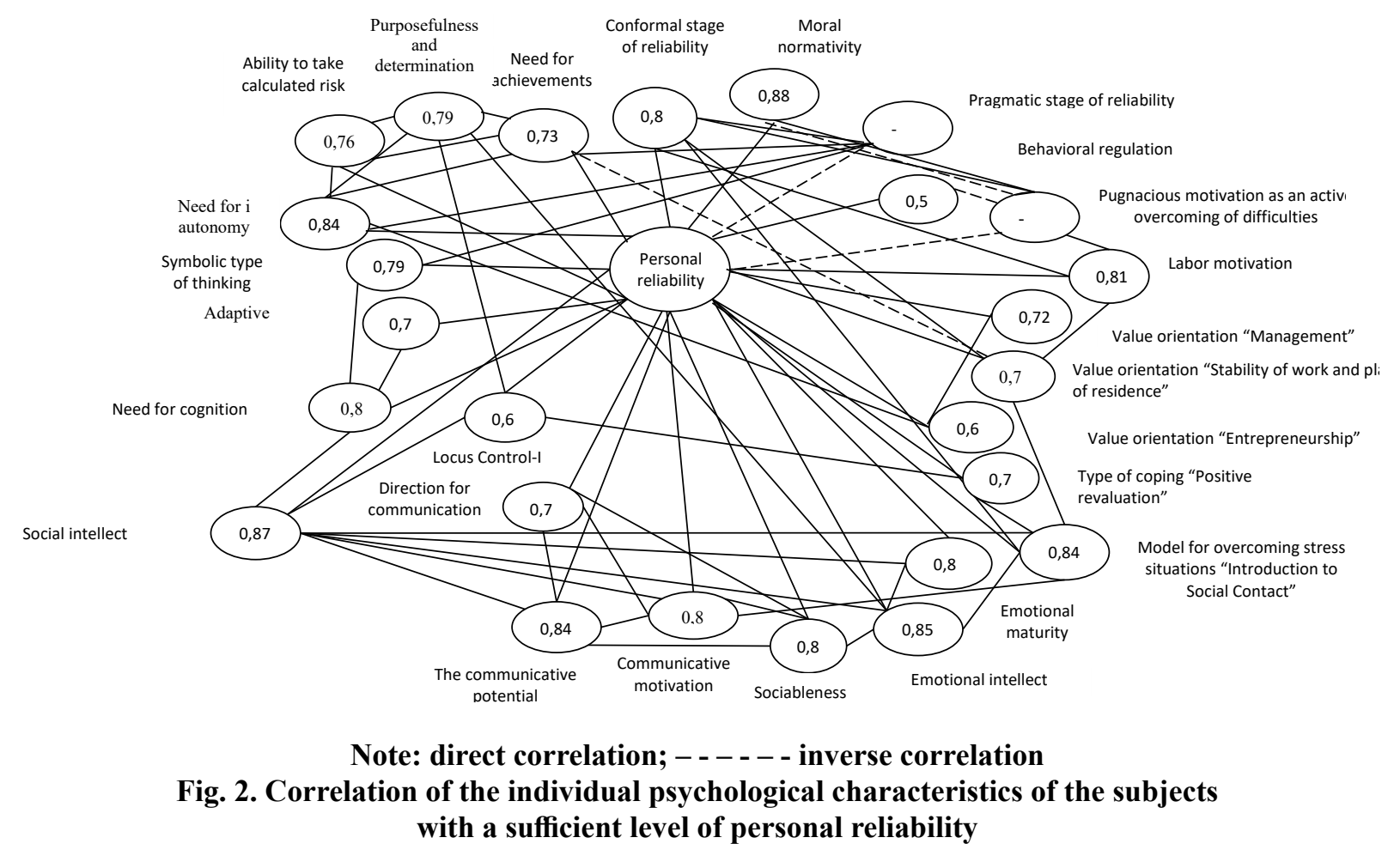


According to the results of correlation analysis, the structure of individual and psychological peculiarities of entrepreneurs with a sufficient level of personal reliability was determined.

So significant factor in the structure was the value-semantic sphere represented by moral normality, value orientations: «Management»; «Stability of work and place of residence»; «Entrepreneurship» and locus control-I.

The presence in the structure of the conformal stage of reliability testifies to the lack of stability and insufficient awareness of the system of moral values. Moral and legal prescriptions are generally adhered to under the influence of the social environment. Moral notions and norms in the structure of mentality exist in consciousness in the form of social stereotypes and emotional experiences.

The specificity of the value-semantic sphere of entrepreneurs with a sufficient level of personal reliability lies in the conflict of utilitarian-pragmatic and moral-ethical aspects in practical activity and everyday life. Among the value orientations in the career are those that give opportunities for leadership, management, high income, increased levels of responsibility and contribution to the success of their organization. It is also important to meet the need for security, security and the ability to predict. The leading sense-oriented orientation in the correlation gap of entrepreneurs with a sufficient level of personal reliability is Locus Control-I, which corresponds to the perception of oneself as a strong person with sufficient freedom of choice in order to build his life in accordance with his goals and understanding of meaning. The inclusion of the pragmatic stage of moral and legal reliability in the individual psychological peculiarities of the subjects with a sufficient level of personal reliability indicates the delays in moral and legal socialization and the conflict between traditional moral values and the universal values of individualism and pragmatism.

The high level of motivation for participation in entrepreneurial activity is characterized by the presence of perverse motivation. These people are attracted by the danger, the situation of struggle and victory, enjoyment of acute sensations. Fear, a sense of danger mobilizes such people, they get the pleasure of it. Also, the correlation galaxy included labor motivation and communicative motivation. This means that the stated purpose of their activities is not to succeed, but to avoid failure. Communicative motivation can be as an instrument of realization in the business of the needs in achievements, in autonomy, in knowledge. In turn, they are mechanisms that set the motivational potential, on the basis of which can be formed the motivation of participation in entrepreneurial activity. The focus on communication shows that for entrepreneurs with a sufficient level of personal security it is inherent to maintain emotional relationships with others, feel a sense of affection, perform joint activities.

The key component in the correlational galaxy is contact, which measures the sociability of the individual, his ability to establish strong and benevolent relationships with others. as a general tendency to mutually beneficial and pleasant contacts with other people, the basis of synergistic (that is capable of self-organization) of the installation of a personality is necessary.

For entrepreneurs with a sufficient level of personal reliability inherent adaptive cognitive style as a subjectspecific system of methods for implementing various types of activity. Trying to work, improving existing methods and practices, offer the following ways to accomplish tasks that can be realized without destroying the existing situation. Preference for changes that occur gradually.

An individual way of analytically synthetic transformation of information predominantly manifests itself in a symbolic type of thinking, for which characteristic features are highly developed analytical abilities, ability to evaluate, calculate and analyze, logical, methodical, diligence (with emphasis on details), problem solving, pragmatism and practicality.

Social intelligence is also an integral part of the correlation gap for providing an adequate level of personal trust to an entrepreneur. This component in the structure of reliability makes it possible to access information about people's behavior, predict their reaction in appropriate circumstances, to demonstrate foresight in relations with others, and to understand the language of non-verbal communication. Evidence of the need to influence others and often combined with developed organizational skills.

The ability to go for a weighted risk also determines the reliability of the individual and is ensured, first of all, by the availability of an adequate assessment of their own capabilities; the assessment of the benefits rather than the possibility of defeat; possibility to operate in conditions of incomplete information; adopting complex but achievable goals; not too ambitious. There is also an inherent election as the main strategy to overcome the stress situation «entry into social contact». The type of reactions to the action of stressors is «positive revaluation». The strategy of positive revaluation involves attempts to overcome negative experiences in connection with the problem due to its positive rethink, considering it as an incentive for personal growth. Positive aspects: Possibility of a positive rethinking of the problem situation. Negative sides: the probability of underestimating the personality of the possibilities of effective solution of the problem situation.

The presence in the correlational galaxy of such indicators as emotional maturity and emotional intelligence indicate their importance in providing a sufficient level of reliability of the individual. They reflect developed sensitivity to their own emotions and awareness of the influence of the emotional sphere on livelihoods, the ability to reflect the emotional state, empathy, emotional competence: identify (recognize, understand) emotions by body reactions, thoughts, etc; analyze your own emotions, feelings; the reasons for their occurrence; tolerate 
mistakes, gain experience; have methods of psycho-physiological self-regulation; have active listening skills; provide and accept emotional support.

The correlation analysis carried out between individual and psychological peculiarities of entrepreneurs with a reduced level of personal reliability, allowed to establish that reliability has a close positive relationship with the following indicators (Fig. 3). The analysis of the structure of the correlation straps of individual psychological peculiarities of entrepreneurs with a reduced level of personal reliability compared with other groups of researchers testifies to the absence of such components as moral normality, behavioral regulation, communication potential, emotional maturity, prosocial value orientations and motives, aspiration and propensity to creativity and innovation. Another key difference is the increase in the number of components that determine the reduction of the level of personal reliability of entrepreneurs to them in the first place are mercenary and pragmatic stage of moral and legal reliability.

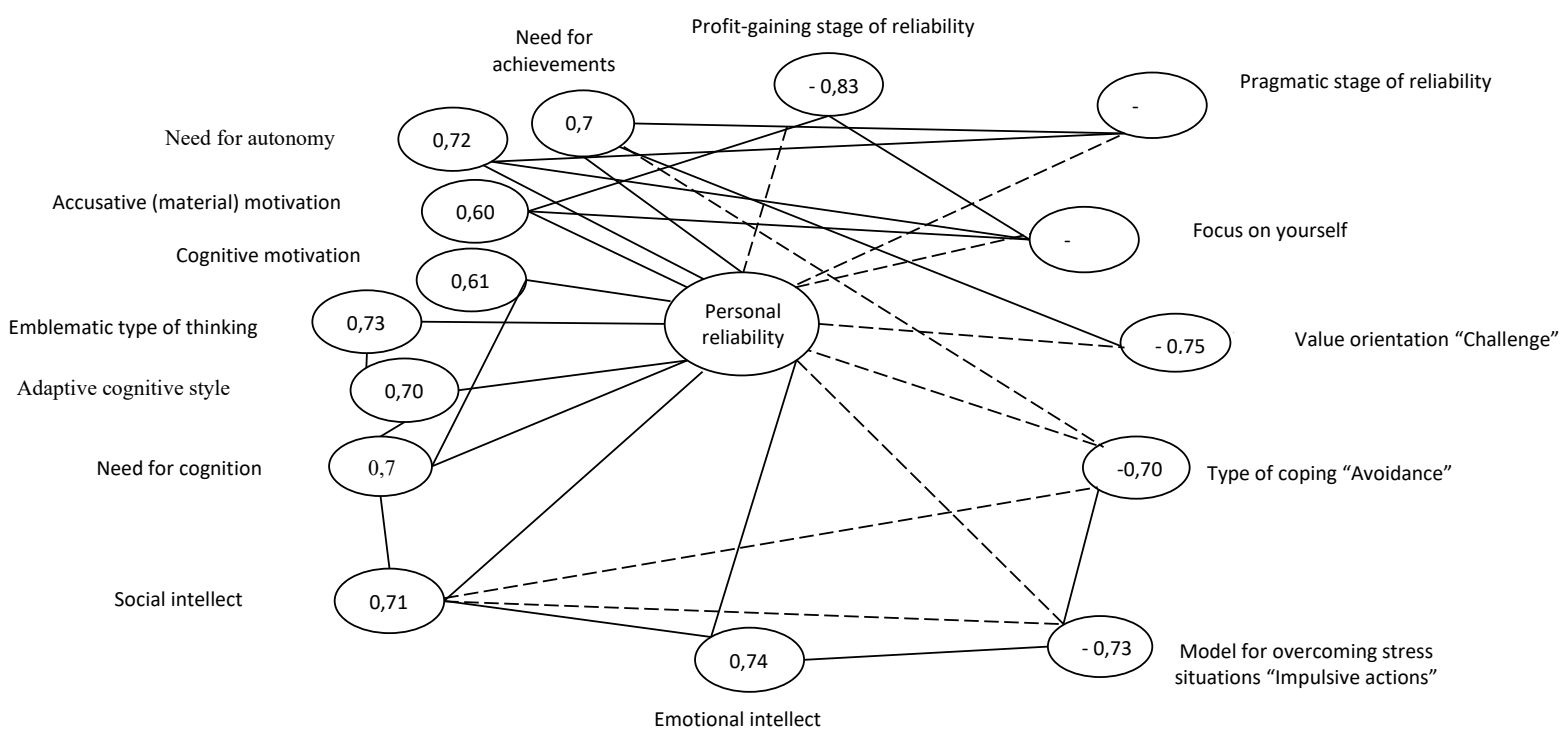

\section{Note: direct correlation; - - - - - - inverse correlation \\ Fig. 3. Correlation of the individual psychological characteristics of the subjects with a reduced level of personal reliability}

For which the characteristic feature is the inversion of personal meanings of moral values in the direction of pragmatism and individualism. Significant influence undergoes a value sphere in the first place is the value orientation «Challenge» which causes the selection of competition as the main style of interaction with others in everyday life and in conflict situations associated with professional activities. They are focused on the solution of consciously complex tasks, overcoming obstacles in order to win the competition. They feel successful only when they are constantly involved in solving complex problems or in a situation of competition.

The predominance of orientation on oneself testifies to the importance of the motives of one's own wellbeing, aspiration of prestige, leadership positions. Such a person tends to be concerned only with his problems and interests and does not react to the needs of others. Professional activities for such a person can act as a means to meet their own needs and aspirations.

Also, the decrease in the personal reliability of business entities is due to behavioral features, namely the use of the situation of uncertainty, the criticism of coping «Avoidance» and the strategy to overcome stress «Impulsive actions».

On the basis of determining the weight of structural components, one can confidently say about their contribution to ensuring the reliability of business entities. So, to study the place, role and weight of each component, which can act as determinants of personal reliability of entrepreneurs, we conducted a factor analysis of the main components of Varimax raw rotation. As a criterion for the significance of the results, the factor weight was 0.40 . This allowed to identify the main factors of the psychological basis of the person, who act as the determining units of the level of reliability of the subject of entrepreneurship [9].

The first factor explains $20.2 \%$ of the total dispersion, including components such as: moral reliability stage $(0,923)$, legal reliability stage $(0,904)$, moral normality $(0,987)$, moral motivation $(0,983)$, value orientation «Professional competence» $(0,869)$, the value orientation «Service» $(0,955)$, the value orientation «Entrepreneurship» $(0,879)$, the meaningful life orientation «The purpose in life» $(0,941)$, the meaning of lifecenteredness «The process of life or interest and emotional saturation of life» $(0,904)$, semislife orientation 
«Effectiveness of life or self satisfaction implementation» $(0,934)$, view of human nature $(0,873)$. Given that this factor reflects the value-semantic sphere of the individual, so this factor was called «Axiological».

The second factor explains $18.7 \%$ of the total dispersion, incorporating such components as: the need for independence / autonomy $(0,974)$, the ability to go for a reasonable (weighted) risk $(0,937)$, commitment and determination $(0,912)$, behavioral regulation $(0,962)$, optimistic motivation $(0,872)$, value orientation «Autonomy (independence)» $(0,971)$, semiotician orientation «Locus control-I» $(0,952)$, autonomy $(0,874)$, model of overcoming stress situations «Assertive actions» $(0,953)$. This factor describes in most concepts of activity, responsibility, self-sufficiency, integrity and integrity of the I-concept of personality, we have defined it as «Proactive».

The third factor that explains $17.2 \%$ of the overall dispersion is absorbed in such components as: communicative potential $(0,904)$, communicative motivation $(0,970)$, normative motivation $(0,901)$, motivation of positive attitude toward people $(0,894)$, altruistic motivation $(0,908)$, communication orientation $(0,938)$, contact $(0,866)$, communication flexibility $(0,831)$, social intelligence $(0,988)$, social support search model $(0,934)$, model of overcoming stress situations «Introduction to social contact» $(0,931)$, the type of coping «Finding a social pi holdings» $(0,954)$, type of coping «Positive revaluation» $(0,802)$, empathy $(0,901)$.

This factor includes both behavioral and cognitive-motivational, value structures and social qualities that characterize the prosocial nature of the person in their content, therefore this factor was defined as «Prosocial».

The concept of the ability to self-organization was presented in the fifth «Synergistic» factor, he explains $15.6 \%$ of the total variance, it includes the following indicators: value orientation «Integration of lifestyles» $(0,878)$; sensory orientation «Locus of control-life or controllability of life» $(0,937)$; type of coping «Selfcontrol» $(0,803)$; Emotional self-regulation $(0,819)$.

$12.5 \%$ of the total dispersion is explained by the sixth factor in which most motivational, cognitive indicators provide realization of creative potential and innovative decisions: the propensity to creativity $(0,956)$; cognitive motivation $(0,907)$; need for cognition $(0,889)$; desire for creativity $(0,933)$; spontaneity $(0,872)$; innovative cognitive style $(0,918)$; creative thinking type $(0,872)$. This factor is defined as «Innovation».

Thus, the correlation and factor analysis conducted allowed to highlight the most important structural components that determine the level of personal reliability of business entities, determine the types of personal reliability.

So personality reliability in the "axiological» type implies the development of a humanist oriented value orientation system that provides the reliability of the individual and the formation of ideological positions, valueideological ideals and standards: the existence of a clear system of individual rules of conduct; the formation of social responsibility and maturity, and determine the personal meaning of entrepreneurial activity [18].

At the heart of personal reliability for the «axiological» type are subjectively selected and taken to action meaningful to the individual values, they find their expression for the purposes of behavior and activities, as well as in the means of their achievement, become the motives for choosing the appropriate mode of action. Valuable orientations act as a tendency to act in a certain way, constitute a higher hierarchical level of dispositional entities of the individual, thus contributing to the role of internal regulators of behavior. Internal content of value orientations are personal meanings, which are manifested in personal settings, in the willingness to act in a certain way [15]. That is, the value-semantic sphere of personality means the elementary components of the deepest layer of the entire intentional structure of the personality in the unity of its objects (aspect of the future), the special experience-possession (aspect of the present) and the preservation of its «achievement» in consciousness (the aspect of the past), which constitutes the internal the world of personality as a «uniquelysubjective being» [12].

The era of globalization has shaped the common value platform of the European world - democracy, tolerance, peace, ecological safety, human rights, solidarity, etc. - which, quite clearly, can serve as an axiology for the training of entrepreneurs. The priority of a person as a subject of economic, social, political and legal activity, and the bearers of the principal features of equality, freedom and volitional self-expression are indisputable and inalienable essential features of a democratic form of government, without which the true democracy becomes desolate and formalized, which necessarily leads to before its decline. Taking into account the global tendencies of the universalization of democratic values and the democratic and humanistic thinking style, today it is necessary to substantiate the need and study the contradictions in the democratic arrangement of a person's way of life, in particular in transformational societies. Particularly acute in transitional societies is the problem of adequate perception of democratic values, as well as the avoidance of frustration in them because of the instability of social structures in the transition period [1].

Personality reliability by the «proactive» type is manifested in the awareness of the subject of his intrinsic values and goals, the subordination of actions to life principles, regardless of the circumstances and circumstances, taking responsibility for himself and his life, in such behavioral features as: initiative and activity; the belief in the choice of choice; the possibility of changing something; readiness to take responsibility; principledness, purposefulness; change (or choice) of circumstances for your tasks. Individuals who are carriers of personal 
reliability for the «proactive» type are inclined to positively assess what is happening, accumulate personal resources, avoid their squandering, and in the case of stress - capable of their rapid mobilization, which requires the presence of highly developed social skills.

The personal reliability of the «prosocial» type in the first place determines the prosocial behavior of business entities, which in its content, mechanisms and forms has many varieties. The main ones include: altruistic and helping behavior, cooperation, empathy, human relations; in a purely economic sense, is fundraising, donation, charity, patronage. It manifests itself in the ability of the individual to decode the social situation from the point of view of the need for assistance, awareness of their own activity potential, readiness to take responsibility in problematic situations, and take active steps to improve or alleviate the life situation of other people $[5 ; 10]$.

The personal reliability of the «prosocial» type ensures the implementation of social entrepreneurship based on social responsibility and social partnership, as counteracting the protracted social and economic crisis in society, its focus on high consumption and material prosperity, pragmatism and competition of market relations, the desire for self-welfare in ignorance the interests of other people produces the growth of selfish dominant in social behavior and the destruction of fundamental moral ethics s values and ideals. Therefore, we can state that the full life of man and as a citizen, and as a personality is impossible without the acquisition of personal meanings of the social level [13].

The personal reliability of the «praxeological» type ensures effective management of the activity through its comprehensive self-examination, self-evaluation, purposeful modeling of conditions and means of improvement on the basis of the synthesis of theoretical knowledge and empirical experience. Represents the dependence of the results of work, first of all, from the previous thorough preparation for its implementation, the degree of preparedness of actions in the broad sense, covering knowledge acquisition, conscious choice of means, methods of analysis and regulation, criteria of emotional and practical evaluation of results.

The personal reliability of the «synergetic» type characterizes the personal development of the subject of entrepreneurial activity not only as a gradual, linear, conflict-free process, but as a process accompanied by contradictions that lead to the transformation of value orientations, self-cognitive and self-conscious activity. From the standpoint of synergetics, professional decisions and actions are determined not only by the knowledge of the laws, the formed skills and abilities, the content and results of analytical and synthetic activity, but also through the understanding of their own mental processes, analysis of the peculiarities of their own style of work.

«Innovative» type of personal reliability of subjects of entrepreneurial activity determines the effect of human cultural activity, the creation of human labor, changes in social behavior of people and the program of personality development, where the creative process is combined with the innovation-innovative, adaptive processes that take place in the innovative forms of social behavior and self-development. The variability of ideas and opportunities for creating value, finding solutions for existing and new challenges, research and experimentation with innovative approaches, combining knowledge and resources to achieve results is also characterized by the manifestation of personal credibility for the «innovative» type.

Based on the EntreComp model of development [17], which suggests that entrepreneurship as competence develops in the process of activity of individuals or institutions in order to create value for others, the progression in entrepreneurship consists of two aspects: the development of ever more autonomy and responsibility for the implementation of ideas and opportunities for value creation; the development of the ability to generate value - from simple and predictable contexts and to complex types of environment that is constantly changing. «Innovative» type of personal reliability of business entities corresponds to the highest - expert level of entrepreneurship development - management of change, innovation and growth due to the competencies required to respond to complex challenges, to live in a constantly changing environment and has a high level of non-predictability (expansion) and focus on new challenges by gaining new knowledge, research, development and innovative abilities to achieve excellence and transformation of that.

Entrepreneurship involves the activities of an entrepreneur who is the creator of his own business, he can create both a new profession and an industry in the existing professions, he is a social innovator.

Conclusion. The problem of ensuring the reliability of business entities should be solved primarily through the study of those personal structures that ensure the stability and optimal level of personality-functional and performance indicators of entrepreneurs at different levels of socio-cultural space. Personality reliability of subjects of entrepreneurial activity includes moral and legal and prosocial, humanistic-oriented values that correspond to the ethics of their chosen professional activities and provide for the recognition of social significance and personal responsibility for the results of entrepreneurial activity.

The problem of ensuring the reliability of business entities should be solved primarily through the study of those personal structures that ensure the stability and optimal level of personality-functional and performance indicators of entrepreneurs at different levels of socio-cultural space. Personality reliability of subjects of entrepreneurial activity includes moral and legal and prosocial, humanistic-oriented values that correspond to the ethics of their chosen professional activities and provide for the recognition of social significance and personal responsibility for the results of entrepreneurial activity. 


\section{References}

1. Андрущенко В. А., Андрущенко Т. В., Савельєв В. Л. Конституціалізація освітнього простору Європи: аксіологічний вимір. Київ: МП «Леся», 2014. 460 с.

2. Гнускіна Г. В. Психологічні чинники професійного вигорання у підприємців: автореф. дис. на здобуття наук. ступеня канд. психол. наук: 19.00.10. Київ, 2016. 22 с.

3. Карамушка Л. М., Худякова Н. Ю. Мотивація підприємницької діяльності: монографія. Львів: Сполом. 2011. 208 c.

4. Кононець М. О. Психологія професійної моральності підприємців: теорія та сучасна практика: монографія. Київ: Омега-Л, 2013. 66 с.

5. Корчакова Н. В. Вікова генеза просоціальності особистості: автореф. дис. на здобуття наук. ступеня д-ра психол. наук: 19.00.07. Київ, 2018. 44 с.

6. Креденцер О. В. Дослідження особливостей розвитку підприємницької активності персоналу освітніх організацій. Актуальні проблеми психологї̈: зб. наукових працьь Інституту психологї імені Г. С. Костюка НАПН України. Т. І: Організаційна психологія. Економічна психологія. Соціальна психологія. Київ, 2015. Вип. 42. С. 114-122.

7. Кулаковський Т. Ю. Психологічні чинники розвитку здібностей до підприємництва: автореф. дис. на здобуття наук. ступеня канд. психол. наук: 19.00.10. Київ, 2010. 20 с.

8. Кульбіда Н. М. Особистісні детермінанти успішної професійної підготовки майбутніх підприємців : автореф. дис. на здобуття наук. ступеня канд. психол. наук: 19.00.07. Київ, 2005. 20 с.

9. Лантух І. В., Малєєв Д. В. Структура індивідуально-психологічних особливостей підприємців 3 різним рівнем особистісної надійності. Fundamental and applied researches in practice of leading scientific schools. 2018. №29(5). P. 11-22. DOI: https://doi.org/10.33531/farplss.2018.5.02.

10. Лантух І. В. Доброчинність і доброчинний соціальний маркетинг українського підприємництва. Науковий вісник Полтавського університету економіки і торгівлі. Серія : Економічні науки. 2010. № 5(2). С. 15-22.

11. Малєєв Д. В. Психологічні чинники розвитку професійної надійності працівників підрозділів превентивної діяльності Національної поліції України: автореф. дис. на здобуття наук. ступеня канд. психол. наук: 19.00.06. Харків, 2016. 22 с.

12. Новая философская энциклопедия: в 4-х томах / науч.-ред. совет: В. С. Степин и др. Москва: Мысль, 2010. T. 4. 2010. 737 c.

13. Павелків Р. В. Феномен просоціальності як новий аспект психологічного аналізу. 3б. наук. праџь РДГУ. 2013. № 2. С. 4-8.

14. Паламарчук О. М. Психологія розвитку екологічно орієнтованої підприємницької діяльності: автореф. дис. на здобуття наук. ступеня д-ра психол. наук: 19.00.01. Київ, 2015. 43 с.

15. Панчук Н. П. Ціннісні орієнтації як системоутворюючий фактор соціально активної позиції майбутнього фахівця. Проблеми сучасної психологї. 2013. Вип. 21. С. 542-551.

16. Стрижов Е. Ю. Нравственно-психологические детерминанты мошенничества: дис.... д-ра психол. н.: 19.00.06. Москва: Акад. упр. МВД РФ, 2011. 400 с.

17. Bacigalupo M., Kampylis P., Punie Y., Van den Brande G. EntreComp: The Entrepreneurship Competence Framework. Люксембург: Publication Office of the European Union. 2016. EUR 27939 EN. Doi:10.2791/593884

18. Maleev D. The use of moral-psychological approach to the problem of development of the professional reliability of personality. Fundamental and Applied Researches in Practice of Leading Scientific Schools. 2014. 1(1). P. 85-102. Retrieved from https://farplss.org/index.php/journal/article/view/145. 